\title{
Entrapped Gray Matter Present
}

National Cancer Institute

\section{Source}

National Cancer Institute. Entrapped Gray Matter Present. NCI Thesaurus. Code C96352.

A morphologic finding that refers to the presence of ectopic gray matter in a tissue sample. 